\title{
VARIASI SPASIAL DAN TEMPORAL SIFAT ALIRAN UNTUK KARAKTERISASI AKUIFER KARST SISTEM PINDUL, KABUPATEN GUNUNGKIDUL
}

\author{
Afid Nurkholis ${ }^{1}$ \\ Tjahyo Nugroho Adji ${ }^{2}$ \\ Eko Haryono ${ }^{3}$ \\ Ahmad Cahyadi ${ }^{4}$ \\ Romza Fauzan Agniy ${ }^{5}$ \\ 1,2,3,4,5 Karst Research Group, Fakultas Geografi, Universitas Gadjah Mada, \\ *corresponding author: afidnurkholis@gmail.com, e.haryono@geo.ugm.ac.id, ahmadcahyadi@geo.ugm.ac.id, \\ romza.fauzan@gmail.com
}

\begin{abstract}
ABSTRAK
Sistem Karst Pindul memiliki keunikan berupa adanya sistem sungai bawah tanah (conduit) dan sistem retakan diffuse. Sumberdaya air pada wilayah ini dimanfaatkan untuk pariwisata dan pertanian. Pengetahuan mengenai perilaku akuifer karst semakin menjadi penting mengingat besarnya manfaat yang diberikan. Water level data logger dipasang pada Goa Pindul (outlet sistem karst) dan Sinking Stream Kedungbuntung. Pengukuran debit pada kondisi tinggi, sedang, dan rendah dilakukan untuk membuat rating curve. Data hujan didapatkan dengan memasang penakar hujan otomatis pada bagian tengah sistem karst. Sebelas kejadian banjir dipilih untuk dihitung konstanta resesi dan persentase aliran dasarnya. Hasil penelitian menunjukkan Sistem Karst Pindul memiliki sifat aliran yang bersifat campuran (mixed). Dominasi aliran conduit disebabkan oleh adanya imbuhan dari sistem pergoaan dan Sinking Stream Kedungbuntung. Sementara itu, dominasi aliran diffuse dijelaskan oleh adanya akuifer dengan tipe retakan diffuse seluas $13,7 \mathrm{~km}^{2}$ (88\% dari luas DTA). Secara spasial, Goa Pindul memiliki pelepasan komponen aliran yang lebih cepat dibandingkan Kedungbuntung. Nilai $\mathrm{Kc}, \mathrm{Ki}$, dan $\mathrm{Kb}$ Goa Pindul (rerata 0,303; 0,705; dan 0,980) lebih kecil dibandingkan Kedungbuntung (rerata 0,325; 0,760; dan 0,990). Selain itu, nilai PAD setiap kejadian banjir Goa Pindul (rerata 42,9\%) juga lebih kecil dibandingkan Kedungbuntung (rerata 47,21\%).
\end{abstract}

Kata kunci : karakterisasi akuifer, konstanta resesi, persentase aliran dasar, Sistem Karst Pindul

\section{Pendahuuan}

Goldscheider dan Drew (2007) mengistilahkan akuifer karst sebagai suatu sistem akuifer yang sulit diprediksi. Karst memiliki tiga sifat aliran yang membuatnya kompleks dan rumit (Cahyadi dkk., 2013a; Cahyadi, 2014). White (1969) dan Atkinson (1977) menerangkan bahwa akuifer karst memiliki sifat aliran diffuse (aliran laminar, mengalir melalui pori-pori homogen) dan conduit (aliran turbulen, mengalir melalui lorong perpipaan). Atkinson (1985) memberikan konsep baru mengenai adanya sifat aliran fissure yang mengalir melalui rekahan batuan. Adanya berbagai sifat aliran tersebut menjadikan metode karakterisasi akuifer yang ada umumnya dikenal sulit diterapkan di akuifer kawasan karst.

Mataair atau outlet sistem karts merupakan lokasi ideal untuk melakukan karakterisasi akuifer karst (Bonacci, 1993; White 2003, Cahyadi dkk., 2013b). Debit aliran pada kedua lokasi merupakan paduan dari ketiga sifat aliran. Raesi dan Karimi (1997) menerapkan kemograf, perhitungan konstanta resesi dan pemisahan aliran dasar pada mataair karst. Malik dan Vojtkova (2012) menggunakan resesi hidrograf untuk menentukan tingkat karstifikasi akuifer karst. Sementara itu, Rashed (2012) menambahkan penggunaan parameter Tp (time to peak), $\mathrm{Tb}$ (time to baseflow) dan time event untuk menentukan derajat karstifikasi.

Penelitian ini dilakukan pada Sistem Karst Pindul, Kecamatan Karangmojo, Kabupaten Gunungkidul yang memiliki luas $15,44 \mathrm{~km}^{2}$. Menurut fisiografi Bemmelen (1949), sistem karst 


\section{PROCEEDING, KONGRES \& PERTEMUAN ILMIAH TAHUNAN KE-2 \\ PERHIMPUNAN AHLI AIRTANAH INDONESIA (PIT-PAAI) \\ 13 - 15 SEPTEMBER 2017, YOGYAKARTA}

ini terletak di Basin Wonosari (Gambar 1), yaitu sebelah selatan dari Karst Gunungsewu yang banyak dijelaskan oleh Danes (1910) dan Lehmann (1936). Sistem Pindul menjadi menarik diteliti karena adanya dua tipe akuifer karst, yaitu tipe aliran diffuse seluas $13,69 \mathrm{~km}^{2}$ dan conduit seluas 1,75 km² (Agniy, 2016; Cahyadi dan Agniy, 2016). Sistem conduit dicirikan dengan adanya jaringan pergoaan. Menurut Haryono (2014), Goa Asri, Goa Greng, Goa Emas, Goa Candi, Goa Suruh, dan Goa Sioyot saling terhubung dari timur ke barat untuk selanjutnya mengimbuh outlet sistem karst yang berada di Goa Pindul. Sistem diffuse memiliki beberapa mataair dan sungai permukaan yang mengimbuh Goa Pindul malalui Sinking Stream Kedungbuntung.

Sistem conduit utamanya dimanfaatkan untuk kegiatan pariwisata, sedangkan sumberdaya air pada sistem diffuse dimanfaatkan untuk pertanian, sumber air minum, mandi, dan mencuci. Pengetahuan mengenai perilaku akuifer karst Sistem Pindul kian menjadi penting mengingat besarnya manfaat yang diberikan (Cahyadi dan Agniy, 2016). Penelitian ini akan melakukan karakterisasi akuifer karst menggunakan perhitungan konstanta resesi dan pemisahan aliran dasar. Penelitian mengenai tema tersebut telah dilakukan pada fisiografi Karst Gunungsewu, yaitu Adji (2009) di Sistem Karst Bribin; Misqi (2010) di Goa Seropan, Goa Toto, dan Mataair Beton; serta Adji dan Bahtiar (2016) di Mataair Petoyan. Oleh karena itu, penelitian ini akan memberikan pengetahuan baru mengenai karakteristik akuifer karst yang berada di fisiografi Basin Wonosari

\section{Metode}

\subsection{Pembuatan Rating Curve dan Hidrograf Aliran}

Hubungan antara debit aliran dengan tinggi muka air (TMA) akan membentuk suatu kurva yang disebut rating curve (Linsley, dkk, 1975; Soewarno, 1991). Kurva ini dibuat melalui pengukuran debit saat kondisi tinggi, sedang, dan rendah, sehingga mewakili variasi debit aliran sepanjang musim. Rating curve menghasilkan koefisien yang dapat digunakan untuk membuat hidrograf aliran (Schulz, 1976). Persamaan rating curve yang akan menghasilkan debit aliran secara kontinu adalah sebagai berikut:

$$
Q=a\left(H-H_{0}\right)^{b}
$$

di mana Q merupakan debit aliran, a dan b merupakan konstanta hasil regresi, $\mathrm{H}$ merupakan TMA yang dicatat secara kontinu, dan $\mathrm{H}_{0}$ merupakan TMA ketika debit bernilai nol.

\subsection{Perhitungan Konstanta Resesi dan Pemilihan Kejadian Banjir}

Konstanta resesi dihitung pada hidrograf banjir yang memiliki waktu resesi cukup. Setelah terjadinya puncak banjir, hidrograf akan mengalami resesi yang dapat dihitung konstantanya. Persamaan kurva resesi menurut Barnes (1940, dalam Schulz, 1976) adalah sebagai berikut:

$$
Q_{t}=Q_{0} e^{-\alpha t}
$$

di mana $\mathrm{Q}_{\mathrm{t}}$ adalah debit pada saat waktu $\mathrm{t}, \mathrm{Q}_{0}$ adalah debit permulaan resesi, dan $\mathrm{e}^{-\alpha}$ merupakan konstanta resesi $(\mathrm{Kr})$. Ploting dalam skala semi-log menunjukkan bahwa persamaan di atas linier sehingga dapat diubah menjadi seperti berikut:

$$
\begin{aligned}
& \ln Q_{t}=-K_{r}\left(t-t_{0}+\ln Q_{0}\right. \\
& K_{r}=-1 / \ln \left(\frac{Q_{t}}{Q_{0}}\right)\left(t-t_{0}\right.
\end{aligned}
$$

Kejadian resesi memiliki tiga komponen aliran. Pertama, streamflow atau aliran conduit yang diukur menggunakan konstanta resesi aliran conduit $(\mathrm{Kc})$. Kedua, interflow atau aliran 


\section{PROCEEDING, KONGRES \& PERTEMUAN ILMIAH TAHUNAN KE-2 \\ PERHIMPUNAN AHLI AIRTANAH INDONESIA (PIT-PAAI) \\ 13 - 15 SEPTEMBER 2017, YOGYAKARTA}

fissure yang diukur menggunakan konstanta resesi aliran fissure (Ki). Ketiga, baseflow atau aliran diffuse yang diukur menggunakan konstanta resesi aliran diffuse (Kb). Menurut Schulz (1976) Kc memiliki julat 0,05-0,5; Ki 0,5-0,85; dan Kb memiliki julat 0,80-0,98.

\subsection{Pemisahan Aliran Dasar}

Aliran dasar dipisahkan menggunakan metode recursive digital filter yang dikembangkan oleh Lyne dan Hollick (1979). Metode ini menggunakan konsep perbedaan frekuensi antara aliran conduit (frekuensi tinggi) dengan aliran diffuse (frekuensi rendah) (Nathan dan McMahon, 1990). Persamaan metode ini adalah sebagai berikut:

$$
\begin{aligned}
& f_{k}=\alpha f_{k-1}+\frac{(1+\alpha)}{2}\left(y_{k}-y_{k-1}\right) \\
& b_{k}=y_{k}-f_{k}
\end{aligned}
$$

di mana $\mathrm{f}_{\mathrm{k}}$ adalah aliran conduit pada waktu $\mathrm{k}, \mathrm{y}_{\mathrm{k}}$ adalah debit total pada pada waktu $\mathrm{k}, \alpha$ adalah $\mathrm{Kb}$, dan $\mathrm{b}_{\mathrm{k}}$ adalah aliran diffuse pada waktu $\mathrm{k}$.

\section{Data}

Penelitian ini menggunakan pasangan data debit aliran dan curah hujan yang diukur setiap interval 15 menit. Water level logger dipasang di Goa Pindul dan Sinking Stream Kedungbuntung untuk mendapatkan data TMA secara kontinu. Penakar hujan otomatis dipasang pada bagian tengah sistem karst. Pencatatan kedua data dilakukan selama enam bulan (Januari-Juni 2017). Lokasi pemasangan alat dapat dilihat pada Gambar 1.

Pengukuran debit aliran dilakukan sebanyak 29 kali. Data ini digunakan untuk membuat rating curve yang akan menghasilkan hidrograf aliran selama enam bulan penelitian. Perhitungan konstanta resesi dilakukan pada hidrograf banjir yang memiliki waktu resesi cukup. Selain itu, hidrograf aliran dan banjir dipisahkan alirannya untuk mendapatkan data persentase aliran dasar bulanan dan pada saat kejadian banjir.

\section{Hasil dan Pembahasan}

\subsection{Variasi Spasial dan Temporal Pelepasan Komponen Aliran}

Goa Pindul dan Sinking Stream Kedungbuntung memiliki sebelas kejadian banjir yang dapat dihitung konstanta resesinya (Tabel 1). Gambar 2.a dan b menunjukkan dua contoh kejadian banjir yang telah dipisahkan komponen alirannya menjadi conduit, fissure, dan diffuse. Pelepasan komponen aliran dari contoh dua kejadian banjir memiliki variasi yang ditunjukkan dengan perbedaan bentuk grafik. Menurut Schulz (1976), pelepasan suatu komponen yang cepat akan memiliki nilai konstanta resesi yang lebih kecil dan memiliki bentuk grafik yang curam.

Bervariasinya pelepasan komponen aliran juga ditunjukkan dengan julat konstanta resesi setiap komponen (Tabel 1). Besarnya julat yang dimiliki konstanta resesi ( $\mathrm{Kb}, \mathrm{Ki}$, dan $\mathrm{Kc}$ ) menunjukkan bahwa sistem Pindul memiliki jenis retakan diffuse, fissure, dan conduit dengan ukuran bervariasi. Smart (1988) melakukan penelitian dengan teknik tracer yang membuktikan bahwa porositas bertipe fissure dan conduit terkadang dorman dan aktif pada curah hujan tertentu.

Sementara itu, nilai $\mathrm{Kb}$ dan $\mathrm{Ki}$ pada kedua lokasi pengukuran memiliki nilai kecil pada banjir besar tanggal 1 dan 5 Maret 2017. Hal ini disebabkan oleh dominannya aliran conduit yang mengimbuh akuifer karst. Dominasi aliran conduit menyebabkan banjir pada tanggal 1 


\section{PROCEEDING, KONGRES \& PERTEMUAN ILMIAH TAHUNAN KE-2 \\ PERHIMPUNAN AHLI AIRTANAH INDONESIA (PIT-PAAI) \\ 13 - 15 SEPTEMBER 2017, YOGYAKARTA}

Maret 2017 memiliki debit puncak (Qp) terbesar, yaitu 30.681 liter/detik pada Goa Pindul dan 11.215 liter/detik pada Kedungbuntung. Adanya aliran conduit juga dibuktikan dengan keruhnya air di Goa Pindul setelah terjadinya hujan.

Rerata konstanta resesi dari Goa Pindul dan Kedungbuntung memiliki nilai <0,5. Nilai ini menunjukkan pelepasan aliran conduit yang cepat (Schulz, 1976; Adji, dkk, 2015; Adji dan Bahtiar, 2016). Cepatnya pelepasan aliran pada Kedungbuntung disebabkan oleh karakteristikya yang berupa sungai permukaan. Limpasan permukaan dari daerah tangkapan air akan mengimbuh saluran sungai yang kemudian langsung dialirakan/dilepaskan. Sementara itu, Goa Pindul sebegai outlet sistem karst diimbuh oleh Sinking Stream Kedungbuntung dan sungai bawah tanah dari sistem pergoaan yang dijelaskan oleh Haryono (2014).

Meskipun demikian, Sistem Karst Pindul masih tergolong baik dalam menyimpan airtanah. Hal ini ditunjukkan dengan rerata nilai Kb pada Goa Pindul dan Kedungbuntung yang lebih dari 0,98 (Tabel 1). Kondisi ini dipengaruhi oleh adanya akuifer dengan dominasi retakan diffuse seluas $13,7 \mathrm{~km}^{2}$ (88\% dari luas sistem karst). Adanya dominasai aliran diffuse dibuktikan dengan tidak pernah keringnya Goa Pindul dan Kedungbuntung pada musim kemarau. Lapisan epikarst masih dapat menyimpan air hujan dan melepaskannya perlahan-lahan.

Secara spasial, Goa Pindul memiliki pelepasan komponen aliran conduit, fissure, dan diffuse yang lebih cepat. $\mathrm{Kb}, \mathrm{Ki}$, dan $\mathrm{Kc}$ Goa Pindul memiliki nilai yang lebih kecil dibandingkan Kedungbuntung. Nilai yang lebih kecil ini disebabkan oleh adanya dua sistem conduit yang mengimbuh Goa Pindul. Sistem pertama adalah Goa Asri, Goa Greng, Goa Emas, Goa Candi, Goa Suruh, dan Goa Sioyot (Haryono, 2014) (Gambar 1). Sistem kedua adalah Sinking Stream Kedungbuntung yang terhubung dengan Goa Tanding untuk selanjutnya mengimbuh Goa Pindul. Kondisi tersebut juga dibuktikan oleh Tb Goa Pindul yang lebih kecil (rerata 13,4 jam) dibandingkan Kedungbuntung (rerata 13,8 jam).

Sinking Stream Kedungbuntung memiliki nilai konstanta resesi yang lebih besar karena diimbuh oleh akuifer dengan dominasi retakan diffuse. Hal ini dibuktikan dengan tidak ditemukannya goa pada daerah tangkapan air (DTA). Selain itu, pumping test dan pembuatan flownet dapat dilakukan oleh Agniy (2016).

\subsection{Variasi Spasial dan Temporal Persentase Aliran Dasar}

Rasio antara aliran dasar dengan debit aliran dapat ditampilkan dalam bentuk rasio setiap bulan dan saat kejadian banjir. Rasio setiap bulan menunjukkan perbandingan antara total aliran dasar dengan total debit aliran per bulannya. Rasio setiap kejadian banjir menunjukkan perbandingan antara nilai aliran dasar dengan debit puncak. Secara keseluruhan, Sistem Karst Pindul memiliki persentase aliran dasar (PAD) $>99 \%$ pada musim kemarau dan $>95 \%$ pada musim penghujan (Gambar 3). PAD tersebut memiliki nilai yang besar dengan julat yang kecil pada musim yang berbeda. Hal ini membuktikan bahwa Sistem Karst Pindul masih baik dalam menyimpan airtanah. PAD juga mendukung hasil perhitungan $\mathrm{Kb}$ yang memiliki nilai besar $(>0,98)$.

Goa Pindul memiliki PAD yang lebih tinggi dibandingkan Kedungbuntung setiap bulannya (Gambar 3). Selisih PAD kedua lokasi cenderung kecil dan konstan pada musim kemarau (bulan Mei dan Juni). Hal ini disebabkan oleh hujan yang mulai jarang terjadi. Sementara itu, April merupakan bulan dimana PAD memliki selisih terbesar. April adalah bulan peralihan antara musim penghujan dengan kemarau sehingga akuifer pada kedua lokasi melepaskan simpanan airnya secara maksimal.

Lebih besarnya PAD bulanan Goa Pindul dikarenakan posisinya yang sebagai outlet sistem karst. Hal ini menjadikannya memiliki DTA yang lebih luas dibandingkan Kedungbuntung. Selain itu, Goa Pindul mendapat imbuhan utama melalui Sinking Stream Kedungbuntung dan 


\section{PROCEEDING, KONGRES \& PERTEMUAN ILMIAH TAHUNAN KE-2 \\ PERHIMPUNAN AHLI AIRTANAH INDONESIA (PIT-PAAI) \\ 13 - 15 SEPTEMBER 2017, YOGYAKARTA}

sistem pergoaan. Kedua imbuhan tersebut mampu menyimpan air yang dibuktikan dengan tetap adanya aliran air pada musim kemarau. Ketika musim kemarau, Goa Greng memiliki debit 360 lt/dt, Goa Sioyot 390 lt/dt, Goa Suruh 130 lt/dt, dan Sinking Stream Kedungbuntung 1580 lt/dt (Agniy, 2016).

Sementara itu, PAD Goa Pindul pada setiap kejadian banjir memiliki nilai yang lebih kecil (rerata 42,90\%) dibandingkan Kedungbuntung (rerata 47,21\%) (Tabel 2). PAD terkecil terjadi pada banjir besar tanggal 1 Maret 2017. Hal ini disebakan oleh dominasi aliran conduit yang mengimbuh akuifer karst. Selalu lebih kecilnya PAD Goa Pindul membuktikan bahwa adanya imbuhan dari sistem pergoaan dan Sinking Stream Kedungbuntung yang menjadikannya melepaskan komponen aliran lebih cepat. Nilai PAD saat kejadian banjir juga mendukung perhitungan konstanta resesi pada kedua lokasi. Goa Pindul memiliki Kb, Ki, dan Kc $(0,98$; 0,705; dan 0,303) yang lebih kecil dibandingkan Kedungbuntung $(0,99 ; 0,760$; dan 0,325).

\section{Kesimpulan}

Sistem Karst Pindul memiliki sifat aliran yang bersifat campuran (mixed). Hal ini ditunjukkan dengan nilai $\mathrm{Kc}, \mathrm{Kb}$, dan PAD bulanan yang dihitung pada Goa Pindul (outlet sistem karst) dan Kedungbuntung (sinking stream yang mengimbuh Goa Pindul). Nilai Kc tergolong cepat dalam melepaskan aliran conduit $(\mathrm{Kc}<0,325)$. Hal ini disebabkan oleh adanya imbuhan dari sistem pergoaan dan sinking stream Kedungbuntung. Sementara itu, nilai $\mathrm{Kb}$ $(>0,98)$ dan PAD bulanan (>95\%) menunjukkan bahwa Sistem Karst Pindul masih baik dalam menyimpan airtanah. Hal ini dijelaskan oleh adanya akuifer dengan dominasi retakan diffuse seluas $13,7 \mathrm{~km}^{2}$ (88\% dari luas DTA).

Secara spasial, Goa Pindul memiliki pelepasan komponen aliran yang lebih cepat dibandingkan Kedungbuntung. Nilai Kc, Ki, dan Kb (rerata 0,303; 0,705; dan 0,980) Goa Pindul lebih kecil dibandingkan Kedungbuntung (rerata 0,325; 0,760; dan 0,990). Selain itu, nilai PAD setiap kejadian banjir Goa Pindul (rerata 42,9\%) juga lebih kecil dibandingkan Kedungbuntung (rerata 47,21\%). Hal ini disebabkan karena Goa Pindul diimbuh oleh sistem pergoaan dan Sinking Stream Kedungbuntung. Sementara itu, Kedungbuntung diimbuh oleh akuifer dengan dominasi retakan diffuse.

\section{Acknowledgements}

Penelitian ini merupakan bagian dari skripsi penulis pertama dan Hibah Penelitian Unggul Perguruan Tinggi (PUPT) Dikti tahun 2016 yang berjudul "Karakterisasi Hidrologi dan Banjir di Sungai Bawah Tanah Goa Pindul untuk Mendukung Pengelolaan Pariwisata Berkelanjutan Berbasis Manajemen Kebencanaan". Penulis menyampaikan ucapan terimakasih kepada Dikti dan Lembanga Penelitian dan Pengabdian Masyarakat (LPPM) Universitas Gadjah Mada selaku pihak yang mendukung kegiatan penelitian ini. Penulis juga ingin mengucapkan terima kasih untuk pihak-pihak lainnya yang terkait dengan berjalannya kegiatan penelitian ini.

\section{Daftar Pustaka}

Adji, T.N. (2009). Variasi spasial-temporal hidrogeokimia dan sifat aliran untuk karakterisasi sistem karst dinamis di Sungai Bawah Tanah Bribin, Kabupaten Gunungkidul, DIY. Desertasi, Fakultas Geografi, Universitas Gadjah Mada.

Adji, T.N., Haryono, E., Fatchurohman, H., Oktama, R. (2015). Diffuse flow characteristics and their relation to hydrochemistry conditions in the Petoyan Spring, Gunungsewu Karst, Java, Indonesia. Geosciences Journal. doi 10.1007/s12303-015-0048-8. 


\section{PROCEEDING, KONGRES \& PERTEMUAN ILMIAH TAHUNAN KE-2 \\ PERHIMPUNAN AHLI AIRTANAH INDONESIA (PIT-PAAI) \\ 13 - 15 SEPTEMBER 2017, YOGYAKARTA}

Adji, T.N., Bahtiar, I.Y. (2016). Rainfall-discharge relationship and karst flow components analysis for karst aquifer characterization in Petoyan Spring, Java, Indonesia. Environmental Earth Sciences 75, p. 735.

Agniy, R.F. (2016). Kajian hidrogeologi karst Sistem Goa Pindul, Kecamatan Karangmojo, Kabupaten Gunungkidul. Skripsi, Fakultas Geografi, Universitas Gadjah Mada.

Atkinson, T.C. (1977). Diffuse flow and conduit flow in limestone terrain in The Mendip Hills, Somerset (Great Britain). Journal of Hydrology 35, p. 95-110.

Atkinson, T.C. (1985). Present and future directions in karst hydrogeology. Ann. Soc. Geoi. Belgique 108, p. 293-296.

Bemmelen, R.W. Van. (1949). The geology of Indonesia Vol. 1 A. The Hauge, Government Printing Office.

Bonacci, O. (1993). Karst springs hydrographs as indicators of karst aquifers. Hydrological Sciences 38(1), p. 51-62.

Cahyadi, A., Ayuningtyas, E.A., Prabawa, B.A. (2013a) Urgensi Pengelolaan Sanitasi dalam Upaya Konservasi Sumberdaya Air di Kawasan Karst Gunungsewu Kabupaten Gunungkidul. Indonesian Journal of Conservation, 2(1), p. 23-32.

Cahyadi, A., Pratiwi, E.S., Fatchurohman, H. (2013b) Metode-metode Identifikasi Karakteristik Daerah Tangkapan Air Sungai Bawah Tanah dan Mata Air Kawasan Karst: Suatu Tinjauan. dalam Marfai, M.A., Widyastuti, M. 2013. Pengelolaan Lingkungan Zamrud Khatulistiwa. Buku Pintal, Yogyakarta. p. 37-49.

Cahyadi, A. (2014) Keunikan Hidrologi Kawasan Karst: Suatu Tinjauan. dalam Cahyadi, A., Prabawa, B.A., Tivianton, T.A., Nugraha, H. (2014) Ekologi Lingkungan Kawasan Karst Indonesia, Edisi 2. Deepublish, Yogyakarta. p. 1-13.

Cahyadi, A., Agniy, R.F. (2016) Analisis Breakthrough Curve untuk Karakterisasi Pelorongan di Sistem Sungai Bawah Tanah Pindul Kabupaten Gunungkidul. Prosiding PIT PAAI Ke-1.

Danes, J.V. (1910). Die karstphanomene in Goenoeng Sewoe auf Java. Tijdschrift der Koninklijke Nederlandsche Aardrijkskundig Genootschap 27, p. 247-260.

Goldscheider, N., Drew, D. (2007). Method in karst hydrogeology. Taylor \& Francis Group, London.

Haryono, E. (2014). Speleogenesis Goa Pindul dan sekitarnya. Laporan Penelitian Hibah Fakultas, Fakultas Geografi, Universitas Gadjah Mada.

Lehmann, H. (1936). Morphologische Studien auf Java (3). Geographis-che Abhandlungen, Stutgart, p. 114.

Lyne, V., Hollick, M. (1979). Stochastic time-variable rainfall-runoff modelling. I.E., Aust., Natl., Conf., Publ., 79(10), p. 89-93.

Linsley, J.R., Kohler, M.A., Paulhus, J.L.H. (1975). Applied hydrology. Tata McGraw-Hill, New Delhi.

Malik, P., Vojtkova, S. (2012). Use of recessioncurve analysis for estimation of karstification degree and its aplication in assesing overflow/underflow condition inclosely spaced karstic springs. Envron. Earth Sci. 65, p. 2245-2257. 


\section{PROCEEDING, KONGRES \& PERTEMUAN ILMIAH TAHUNAN KE-2 \\ PERHIMPUNAN AHLI AIRTANAH INDONESIA (PIT-PAAI) \\ 13 - 15 SEPTEMBER 2017, YOGYAKARTA}

Misqi, M. (2010). Analisis konstanta resesi sungai bawah tanah untuk karakterisasi pelepasan komponen akuifer karst (studi kasus: Mataair Beton, Sungai Bawah Tanah Seropan, dan Sungai Bawah Tanah Bribin, Kab. Gunungkidul, Provinsi DIY. Skripsi, Fakultas Geografi, Universitas Gadjah Mada.

Nathan, R.J., McMahon, T.A. (1990). Evaluation of automated techniques for baseflow and recession analysis. Water Resources Research 26(7), p. 1465-1473.

Raeisi, R., Karami, G. (1997). Hydrochemographs of Berghan karst spring as indicators of aquifer characteristics. Journal of Cave and Karst Studies 59(3), p. 112-118.

Rahaningmas, F.R. (2013). Geologi dan hubungan antara fasies karbonat dan jenis porositas terhadap pembentukan Goa Pindul, Desa Bejiharjo dan sekitarnya, Kecamatan Karangmojo, Kabupaten Gunungkidul, DIY. Skripsi, Jurusan Teknik Geologi, Fakultas Teknologi Mineral, AKPRIND.

Rashed, K.A. (2012). Assesing degree of karstification: a new method of classifying karst aquifers. in: Proceedings of the International Water Technology Conference, IWTC, $16^{\text {th }}$. Istanbul, Turkey.

Schulz, E.F. (1976). Problems in applied hydrology. Water Resources Publication, Colorado.

Smart, C.C. (1988). Artificial tracer techniques for the determination of structure of conduit aquifer. Groundwater Journal 26(4).

Soewarno. (1991). Hidrologi - pengukuran dan pengolahan data aliran sungai - hidrometri. Penerbit Nova, Bandung.

White, W.B. (1969). Conceptual models for carbonate aquifers. Ground Water 7(3).

White, W.B. (2003). Conceptual models for karstic aquifers. Speleogenesis and Evolution of Karst Aquifers (1), p. 2. 
PROCEEDING, KONGRES \& PERTEMUAN ILMIAH TAHUNAN KE-2

PERHIMPUNAN AHLI AIRTANAH INDONESIA (PIT-PAAI)

13 - 15 SEPTEMBER 2017, YOGYAKARTA

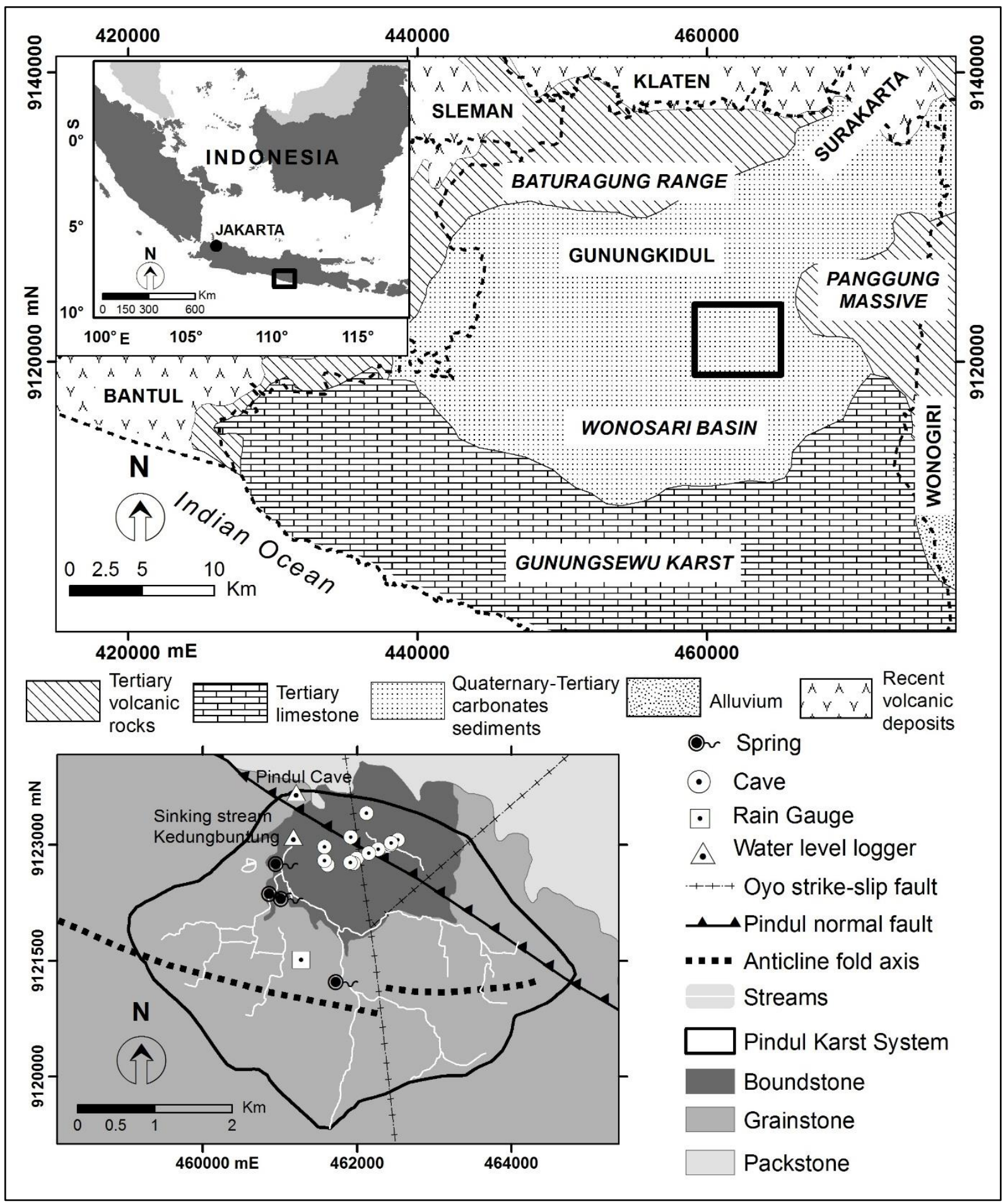

Gambar 1. Geologi lokal dan regional Sistem Karst Goa Pindul (Bemmelen, 1949 dan Rahaningmas 2013) 
PROCEEDING, KONGRES \& PERTEMUAN ILMIAH TAHUNAN KE-2

PERHIMPUNAN AHLI AIRTANAH INDONESIA (PIT-PAAI)

13 - 15 SEPTEMBER 2017, YOGYAKARTA
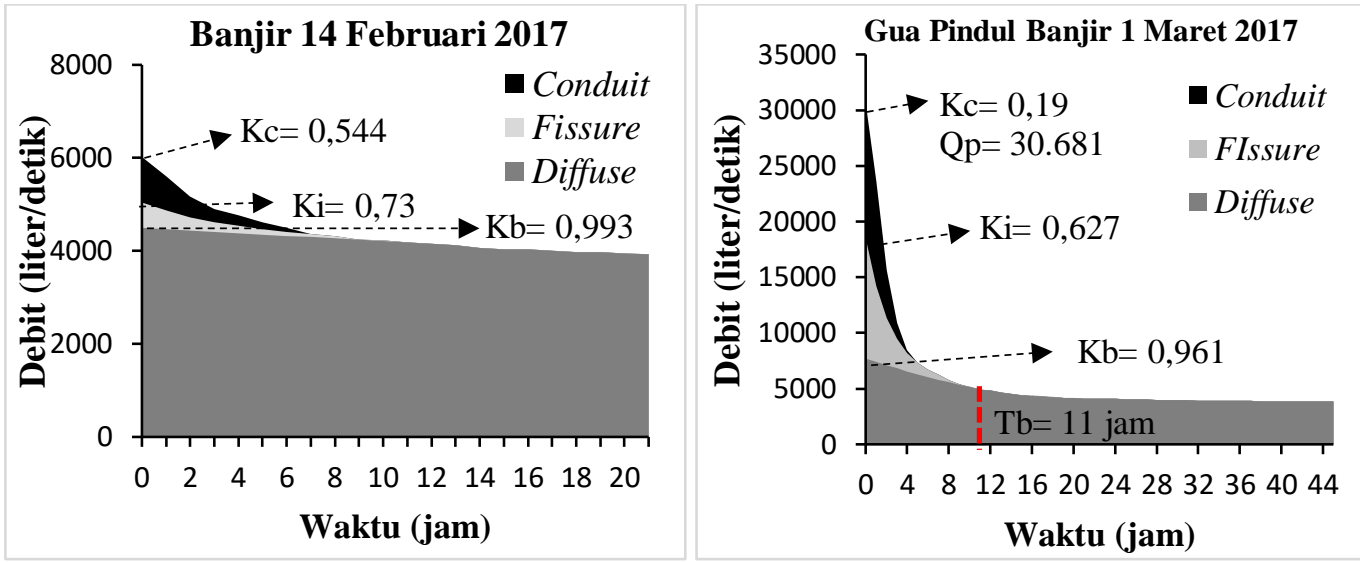

Gambar 2.a. Hidrograf resesi Goa Pindul pada banjir 14 Februari 2017 dan 1 Maret 2017
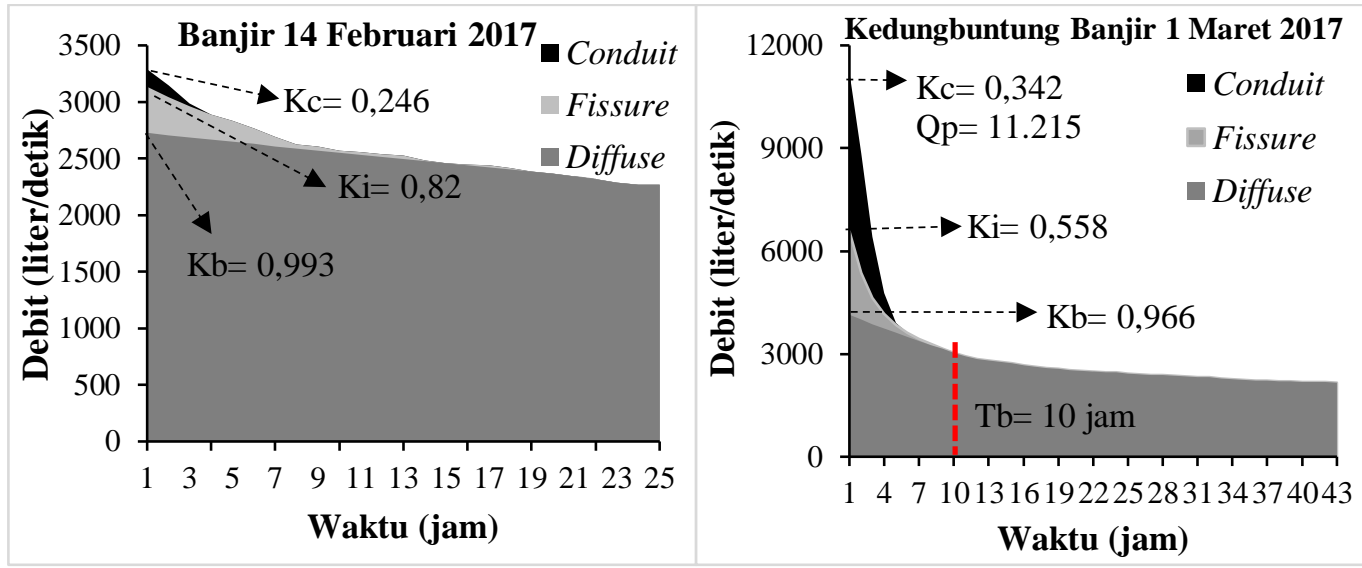

Gambar 2.b. Hidrograf resesi Kedungbuntung pada banjir 14 Februari 2017 dan 1 Maret 2017

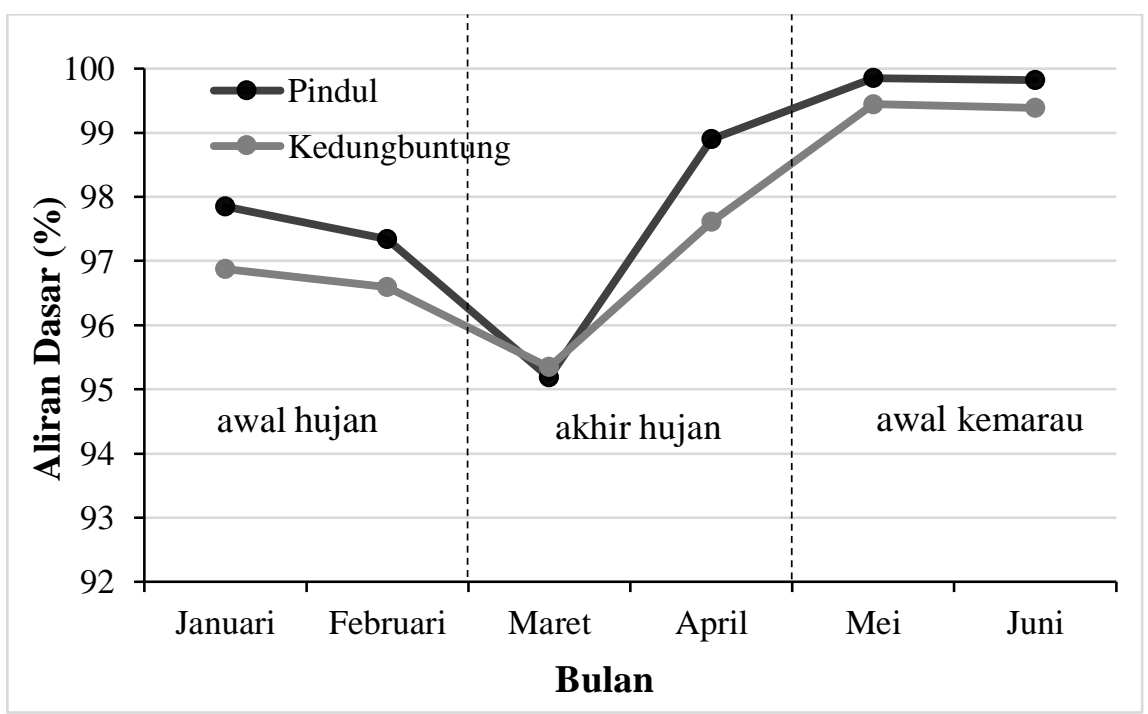

Gambar 3. Variasi PAD bulanan di Goa Pindul dan Sinking Stream Kedungbuntung 


\section{PROCEEDING, KONGRES \& PERTEMUAN ILMIAH TAHUNAN KE-2 \\ PERHIMPUNAN AHLI AIRTANAH INDONESIA (PIT-PAAI) \\ 13 - 15 SEPTEMBER 2017, YOGYAKARTA}

Tabel 1. Konstanta resesi dan Tb dari Goa Pindul dan Sinking Stream Kedungbuntung.

\begin{tabular}{|c|c|c|c|c|c|c|c|c|c|c|}
\hline \multirow[t]{2}{*}{ Tanggal } & \multicolumn{2}{|l|}{$\mathrm{Kc}$} & \multicolumn{2}{|l|}{$\mathrm{Ki}$} & \multicolumn{2}{|l|}{$\mathrm{Kb}$} & \multicolumn{2}{|c|}{ Qp (liter/dt) } & \multicolumn{2}{|c|}{$\mathrm{Tb}$ (jam) } \\
\hline & $\begin{array}{l}\text { Goa } \\
\text { Pindul }\end{array}$ & $\begin{array}{l}\text { Kedung- } \\
\text { buntung }\end{array}$ & $\begin{array}{l}\text { Goa } \\
\text { Pindul }\end{array}$ & $\begin{array}{l}\text { Kedung- } \\
\text { buntung }\end{array}$ & $\begin{array}{l}\text { Goa } \\
\text { Pindul }\end{array}$ & $\begin{array}{l}\text { Kedung- } \\
\text { buntung }\end{array}$ & $\begin{array}{l}\text { Goa } \\
\text { Pindul }\end{array}$ & $\begin{array}{l}\text { Kedung- } \\
\text { buntung }\end{array}$ & $\begin{array}{l}\text { Goa } \\
\text { Pindul }\end{array}$ & $\begin{array}{l}\text { Kedung- } \\
\text { buntung }\end{array}$ \\
\hline $5 / 1 / 2017$ & 0,289 & 0,327 & 0,681 & 0,71 & 0,994 & 0,993 & 10.320 & 4.626 & 15 & 13 \\
\hline $14 / 1 / 2017$ & 0,37 & 0,389 & 0,848 & 0,759 & 0,994 & 0,995 & 5.874 & 3.341 & 18 & 11 \\
\hline $1 / 2 / 2017$ & 0,288 & 0,262 & 0,743 & 0,728 & 0,992 & 0,99 & 11.132 & 4.934 & 14 & 18 \\
\hline $3 / 2 / 2017$ & 0,155 & 0,439 & 0,673 & 0,706 & 0,991 & 0,992 & 5.617 & 5.617 & 20 & 15 \\
\hline $14 / 2 / 2017$ & 0,544 & 0,246 & 0,73 & 0,82 & 0,993 & 0,993 & 6.019 & 3.289 & 12 & 19 \\
\hline $1 / 3 / 2017$ & 0,19 & 0,342 & 0,627 & 0,558 & 0,961 & 0,966 & 30.681 & 11.215 & 11 & 10 \\
\hline $5 / 3 / 2017$ & 0,159 & 0,292 & 0,596 & 0,655 & 0,981 & 0,982 & 15.666 & 6.644 & 11 & 11 \\
\hline $16 / 3 / 2017$ & 0,303 & 0,302 & 0,65 & 0,82 & 0,99 & 0,99 & 10.886 & 4.899 & 12 & 12 \\
\hline $25 / 3 / 2017$ & 0,353 & 0,431 & 0,786 & 0,825 & 0,98 & 0,998 & 5.395 & 3.532 & 10 & 16 \\
\hline $31 / 3 / 2017$ & 0,301 & 0,274 & 0,773 & 0,89 & 0,96 & 0,989 & 13.213 & 5.796 & 11 & 16 \\
\hline $26 / 4 / 2017$ & 0,381 & 0,275 & 0,652 & 0,888 & 0,992 & 0,993 & 12.647 & 5.614 & 13 & 11 \\
\hline rerata & 0,303 & 0,325 & 0,705 & 0,76 & 0,98 & 0,99 & - & - & 13,4 & 13,8 \\
\hline $\max { }^{*}$ & 0,544 & 0,439 & 0,848 & 0,89 & 0,994 & 0,998 & - & - & 20 & 19 \\
\hline $\min ^{*}$ & 0,155 & 0,246 & 0,596 & 0,558 & 0,96 & 0,966 & - & - & 10 & 10 \\
\hline
\end{tabular}

max nilai maksimum, min nilai minimum, ${ }^{*}$ julat nilai (minimum - maksimum)

Tabel 2. PAD setiap kejadian banjir.

\begin{tabular}{|c|c|c|c|c|c|c|}
\hline \multirow[t]{2}{*}{ Tanggal } & \multicolumn{3}{|c|}{ Goa Pindul } & \multicolumn{3}{|c|}{ Kedungbuntung } \\
\hline & $\begin{array}{l}\text { Qp } \\
\text { (lt/detik) }\end{array}$ & $\begin{array}{l}\mathrm{Qb} \\
\text { (lt/detik) }\end{array}$ & $\begin{array}{l}\text { PAD } \\
(\%)\end{array}$ & $\begin{array}{l}\text { Qp } \\
\text { (lt/detik) }\end{array}$ & $\begin{array}{l}\mathrm{Qb} \\
\text { (lt/detik) }\end{array}$ & $\begin{array}{l}\text { PAD } \\
(\%)\end{array}$ \\
\hline $5 / 1 / 2017$ & 10.320 & 4.271 & 41,39 & 4.626 & 2.227 & 48,15 \\
\hline $14 / 1 / 2017$ & 5.874 & 3.764 & 64,07 & 3.341 & 2.028 & 60,69 \\
\hline $1 / 2 / 2017$ & 11.132 & 5.041 & 45,29 & 4.934 & 2.511 & 50,89 \\
\hline $3 / 2 / 2017$ & 12.867 & 4.894 & 38,04 & 5.617 & 2.746 & 48,9 \\
\hline $14 / 2 / 2017$ & 6.019 & 4.144 & 68,85 & 3.289 & 2.375 & 72,23 \\
\hline $1 / 3 / 2017$ & 30.681 & 5.512 & 17,97 & 11.215 & 2.721 & 24,26 \\
\hline $5 / 3 / 2017$ & 15.666 & 4.371 & 27,9 & 6.644 & 2.241 & 33,73 \\
\hline $16 / 3 / 2017$ & 10.886 & 4.069 & 37,38 & 4.899 & 2.011 & 41,05 \\
\hline $25 / 3 / 2017$ & 7.006 & 4.375 & 62,45 & 3.532 & 2.252 & 63,76 \\
\hline $31 / 3 / 2017$ & 13.213 & 4.232 & 32,03 & 5.796 & 2.062 & 35,57 \\
\hline $26 / 4 / 2017$ & 12.647 & 4.615 & 36,49 & 5.614 & 2.250 & 40,07 \\
\hline rerata & & & 42,90 & & & 47,21 \\
\hline $\max$ & & & 68,85 & & & 72,23 \\
\hline $\min$ & & & 17,97 & & & 24,26 \\
\hline
\end{tabular}

